\title{
Burying America's Malls: Cyclical Capital, Commodity, and Creative Destruction
}

\section{Richard Kirk}

Dr. Ipsita Chatterjee (Mentor and Co-editor)

"Permanently Closed," my GPS warned after I thumbed in the address of the Valley View Mall in Dallas, Texas. This mall had once boomed, having peaked in popularity back around 1990. Like shopping malls across America, Valley View Mall and Event Center was a hub for commercial and social exchange - a magnet for bona fide shopaholics, boredom-stricken teenagers, and everyone in between. Now, the city of Dallas calls it an eyesore, and is suing to have the defunct mall demolished (Wilonsky, 2018). Nothing is left but the concrete, minus some boards and padlocks that secure the massive building from would-be squatters and other trespassers. The sprawling, asphalt-laden parking lot (once surely the site of squabbles over scarce parking) is now deserted. This is a "dead mall" - and carcasses of them riddle America. Here, I will explore a number of aspects related to the phenomenon of declining malls. I attempt to uncover the mall's relationship to capital in the American urban setting with particular reference to the Sun Belt, the regional context of my personally investigated malls. I also attempt to discern why the concrete remains of malls are left to litter the urban landscape, and, perhaps most importantly, to discover the culprit(s) behind the malling industry's decline. Finally, I endeavor to connect these realizations in order to apprehend a more holistic image of the shopping mall's decline in the American urban context.

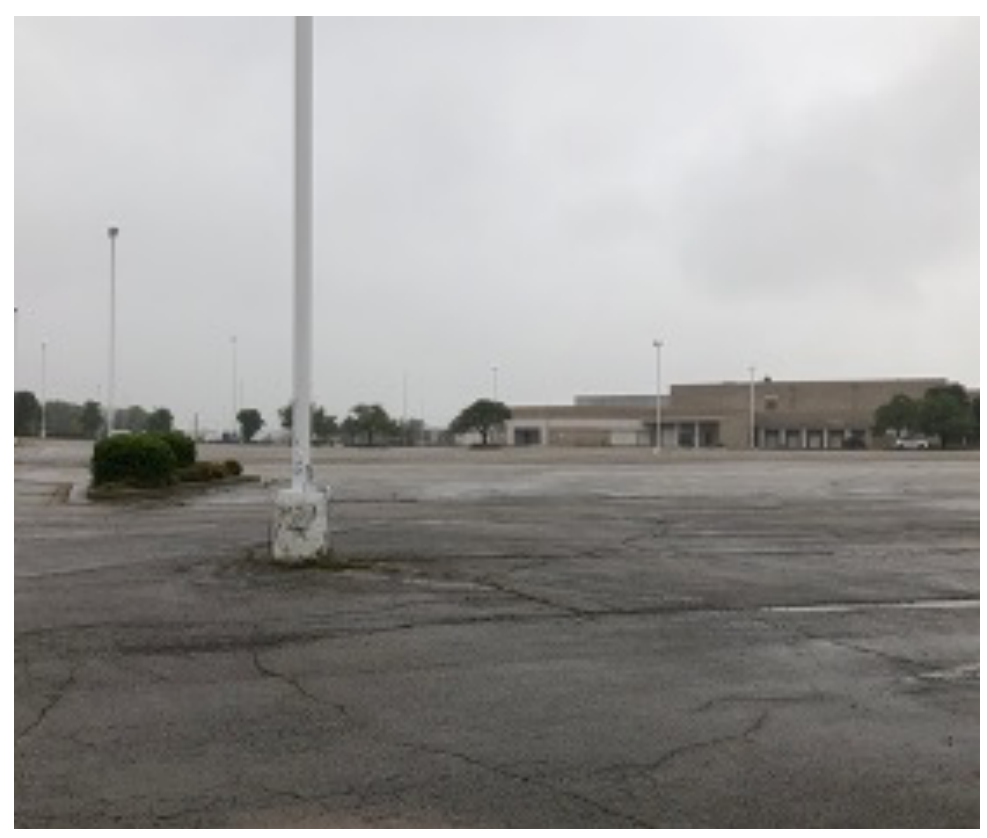

Valley View Mall and Event Center Parking Lot. 04/13/2019. Photograph by author. 
According to geographer Jon Goss in his article "The 'Magic of the Mall': An Analysis of Form, Function, and Meaning in the Contemporary Retail Built Environment," the shopping mall is carefully contrived. It is a built environment that utilizes spectacle to exhibit commodity and entice awed consumers inside. Goss writes about the way in which the mall's entrance "beckons" the shopper as they traverse the bleak parking lot, decorated in a way that is "suggestive of an oasis or sanctuary inside" (Goss, 1993). Upon entering, one sees that "[t]he utopia is kept scrupulously clean and orderly, without any material contamination nor hint of the gradual obsolescence that characterizes material objects" (Goss, 1993). Capital has erected a landscape in its image - à la David Harvey - a built environment expressly designed to fuel accumulation for accumulation's sake - masking the fleeting nature of material value. Throughout the latter part of the 20th and continuing into the 21 st century until the mid-2000s, such spectacular malls sprang up in most every major city, oftentimes with multiple cohabiting the same cityscape. It was this spatial ubiquity that, in part, contributed to the demise of the American cultural staple. Josh Sanburn writes in "Why the Death of Malls is About More Than Shopping" published in Time, "There is an estimated $26 \mathrm{sq}$. $\mathrm{ft}$. of retail for every person in the U.S., compared with about 2.5 sq. ft. per capita in Europe" (Sanburn, 2017). What this indicates is that there is simply too much space dedicated to retail in America to allow for so many malls. That such a problem would arise seems like common sense - probably because it is. Capital frivolously erected mall after mall for the sake of profit accumulation, erecting them in close geographic proximity to other malls and retail outlets despite the impending and inevitable emergence of a hyper-saturated retail environment. This is but a microcosm of the shortsightedness that we know to characterize capital. Certainly profit accumulation in this over-retailed arena is unsustainable, but capital does not operate with such foresight. It hastily builds in order to fuel its insatiable hunger for extracted surplus value.

For years, damning statistics reflecting an industry decline have been reported - some of which indicate a relationship between the decline of malls and climbing e-commerce. The rise of online shopping is, after all, the most readily namable suspect in the mall killer case.

Driving to the mall takes time and navigating it is cumbersome, so why bother when commodity is the tap of a smart phone away? Wolf Richter writes in his Business Insider piece "Nothing Can Stop the Shift to Online Shopping" that the stores getting hit the hardest by the online shopping trend "are typically the stores that populate the malls. Department store sales, which peaked in 2001, have gotten crushed by e-commerce. Despite 16 years of inflation and population growth since then, department-store sales have plunged 35\%" (2017). Richter even includes a nice graph to illustrate the point. Further expanding on this decline, a Forbes article by Tim Worstall entitled "The Shopping Malls Really Are Being Killed by Online Shopping" notes that "about 80 percent of the country's 1,200 malls are considered healthy, reporting vacancy rates of 10 percent or less. But that compares with 94 percent in 2006, according to CoStar Group, a leading provider of data for the real estate industry" - signaling what retail analyst D.J. Busch calls the beginning of "a death spiral" (qtd. in Worstall, 2015). So, it has been no secret that malls are dying at an alarming rate. 


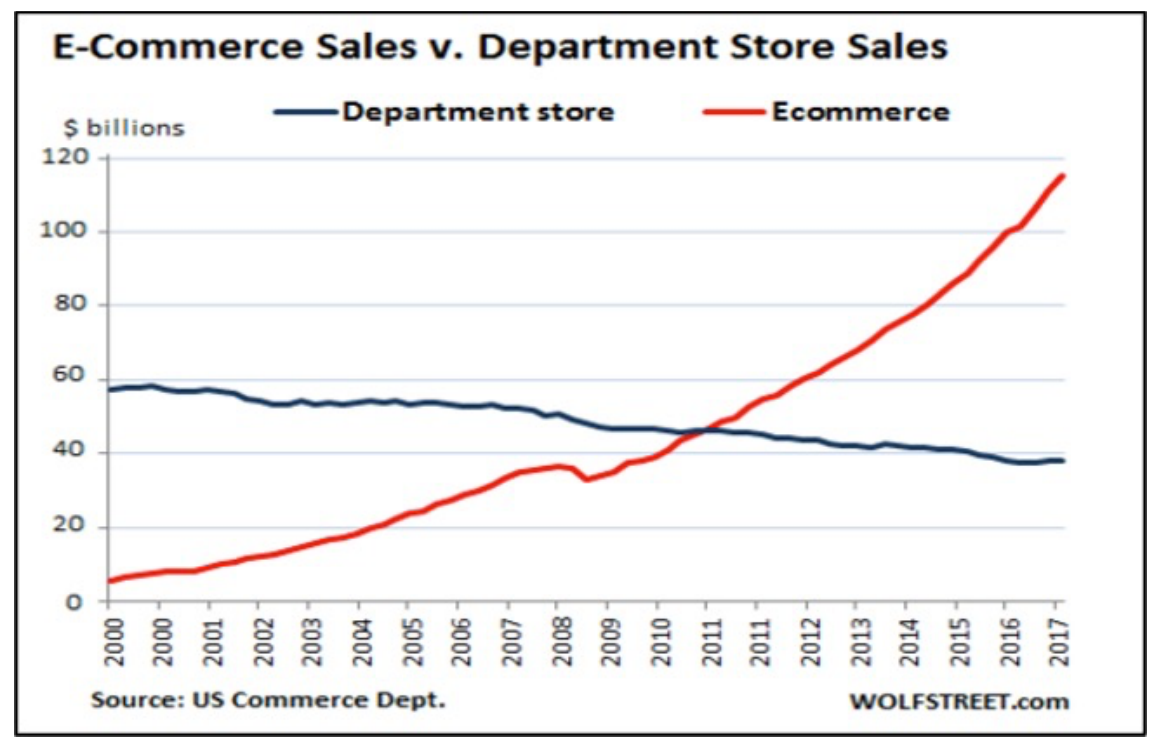

Source: Richter, 2019.

In Denton, I made a trip to the Golden Triangle Mall. Upon walking in through the main entrance, one is greeted by the gloomily lit gated entrance to what had previously been a Sears outlet; it was one of 72 nationwide to close due to plummeting sales (D'innocenzio, 2018). Traveling a bit farther down the corridor, I found the old Dillard's "Men's Department" entrance padlocked. What had been the men's clothing section is no longer an extant portion of the store. Curious about the reason for the apparent downsizing, I spoke to a longtime employee in the Customer Service department:

The phones used to ring all the time, but now it's really slow. We get a lot of people who call to return things they've bought from the [Dillard's] online store, and we have to process those. That's really what did it, people going online and buying instead of coming in. I can hardly get out of the parking lot here without seeing Amazon trucks driving by. So, they had to close off the old Men's [Department] and move it all over here.

During our exchange, she also mentioned that the Dillard's at Music City Mall in Lewisville, Texas, is being converted into a thrift store. "That's another thing that's doing it, I'm telling you. All these thrift stores," she offered up, as though this were a reason for failing malls. Of course, I held my tongue. 


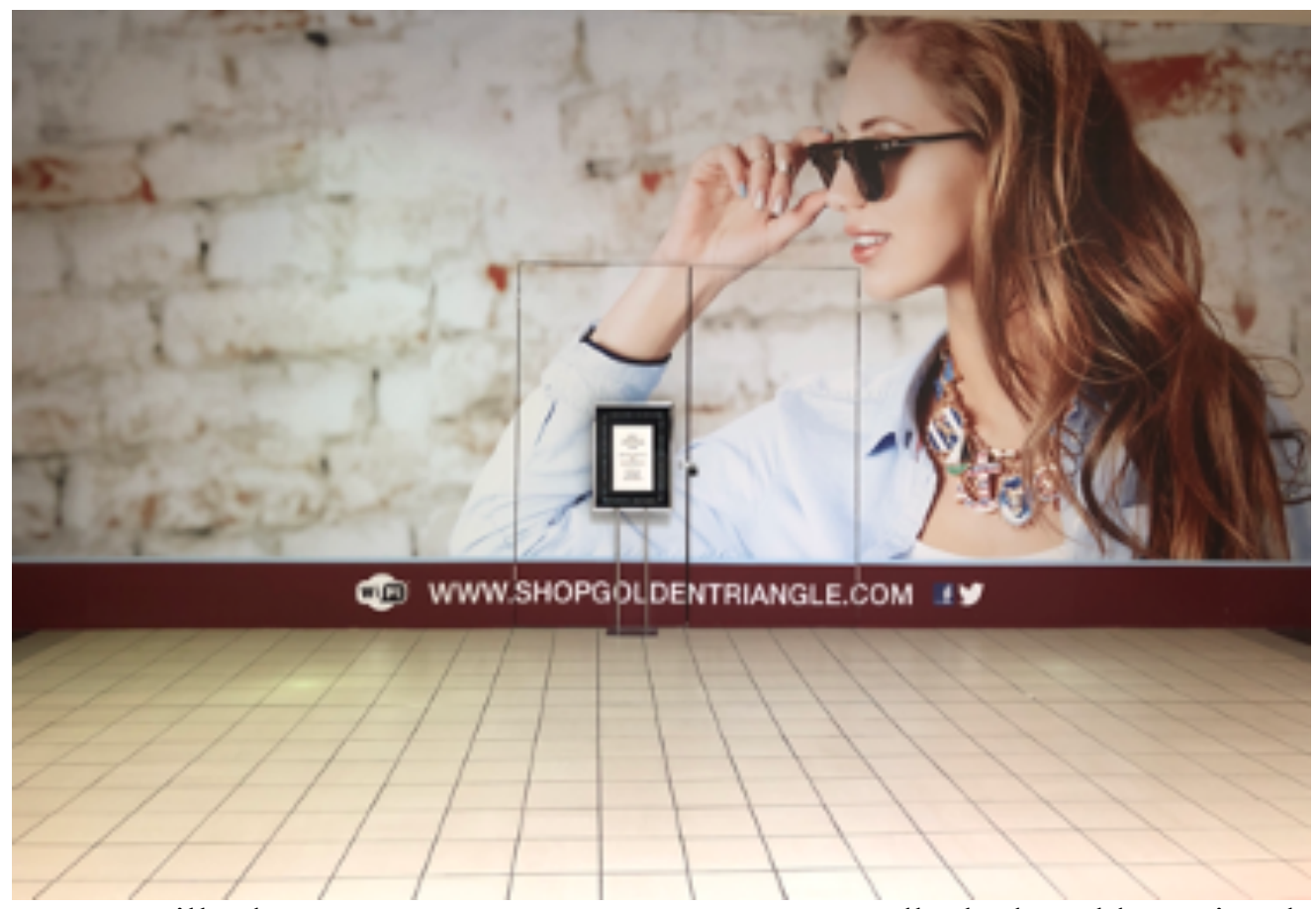

Former Dillard's Men's Department entrance now padlocked, Golden Triangle Mall. Denton, Texas. 04/13/2019. Sign reads: "Dillard's men's department now located inside store. We apologize for any inconvenience. Thank you, Dillard's management." Photograph by author.

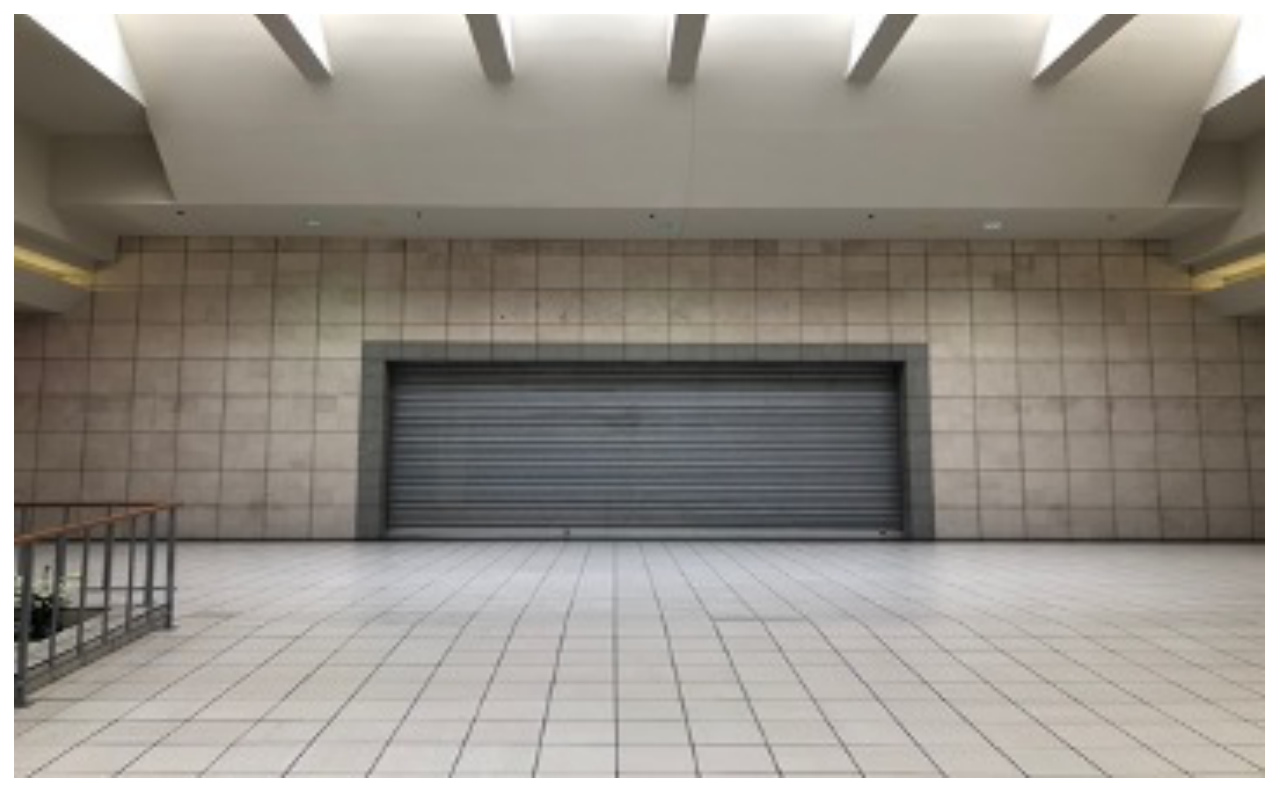

Former Sears entrance, Golden Triangle Mall. Denton, Texas. 04/13/2019. Photograph by author.

It was clear that no serious consideration had been given to the relationship between declining malls and the rising popularity of thrift shops, else a 
comment of that sort would not have been aired. That people cannot afford to shop at high-end malls and instead browse the selection at their local Goodwill is surely the product of a greater systemic problem. Clearly, thrift shops have not "done in" the American mall. What is important to understand, however, is that neither have the isolated phenomena of online shopping and over-malling. This is not to say that online shopping and over-malling are not to blame; indeed they partly are. But the virtual marketplace and needless plethora of spectacular malls is merely part of a much larger story, one that implicates Harvey's notion of cyclical capital.

To ascertain the role of capital in the decline of the American mall, I needed to situate the malling phenomenon into some necessary context. Harvey describes the way in which capital moves throughout a landscape, fleeing from place to place in response to crises of over-accumulation that invariably punctuate capital's predatory occupation of space. Capital is afflicted by a habitual problem, he says. It over-invests in a created landscape to such a degree that it can generate no further profit. It is this zenith of gain that he calls the "crisis of over-accumulation" (Harvey, 1990).

Consequently, capital must abandon its host environment and relocate, seeking out a new market in which to invest and extract additional surplus value. Yet the "flow" of capital into a new environment proves only to be a temporary treatment for a chronic condition. Crises of over-accumulation punctuate capital's tenure wherever it gluttonously resides.

Harvey modeled his circuits of capital with specific reference to Rust Belt America and industrialized Western Europe, but the model contains sufficient room and nuance to be applicable elsewhere, too. $\mathrm{He}$ posits that capital begins by over-investing in what he calls the primary circuit, that is, the realm of manufacturing and industry. In places like the Sun Belt, the primary circuit is characterized by agriculture and mineral resource extraction as opposed to extensive factory and mill production (Tretter, 2016). Then upon crisis, capital moves into the secondary circuit, the realm of urban housing and development. It transforms urban landscapes into predacious environments expressly purposed to aid in its gain, seizing control of urban necessity (housing) and commodity (retail centers). Finally, after yet another crisis of overaccumulation, it moves into the tertiary circuit - the most ethereal of markets. These namely concern research and development, software, e-commerce, and technologies (Harvey, 1990). The shopping mall, therefore, we can comfortably situate within the secondary circuit, as it surely falls within the scope of "urban development".

In the secondary circuit, capital has erected spectacle after spectacle to exhibit commodity in the urban space - from theme parks to stadiums to shopping malls - all purposed to fuel profit accumulation. It is virtually inarguable that mall overinvestment is occurring, because its consequences are demonstrably wreaking havoc; stores inside of shopping malls are closing, and entire malls are dying. Given what we know about Harvey's model, one might therefore expect that this capital in crisis would be fleeing uniformly into the realm of the tertiary circuit - but this is not so. While understanding Harvey's circuits of capital is useful in situating the mall within its capital context, the reality of capital inside of the circuits proves to be much more dynamic. By exposing the nature of capital at the level of the secondary circuit, I can bring the cause of the mall's decline into sharper focus. Remember Valley View Mall and Event Center, the dead mall that the city of Dallas wants torn down for being an eyesore? This mall serves an illustrative case 
study to explore capital's movement within the secondary circuit.

The once-booming mall is now but a shell of its past self: a huge, desolate concrete structure with a sprawling ghost town for a parking lot. The nature of its construction is such that demolition is rendered difficult and very expensive. It is an immobile, implastic built environment. Capital knew this, but had a backup plan if the mall failed: it would simply move on. And when the Valley View Mall and Event Center failed, capital did exactly that, leaving behind in its wake an enormous concrete shell devoid of all use value. (To complete Harvey's sentiment, capital creates a landscape in its image only to destroy it at a later date.) The landscape left behind has been effectively defaced, destroyed, stripped of its use value, because to tear down the mall is just too expensive a task. That is why the carcasses of so many dead malls litter the American landscape; to do anything about their ghostly shells is simply beyond the capacity of local municipalities and bankrupt owners. Harvey, drawing from economist Joseph Schumpeter, calls it "creative destruction" - when capital shortsightedly erects a landscape that is functionally designed to aid in profit accumulation, only to turn around and destroy it when it no longer serves capital's interests. But where is capital going, if not the tertiary circuit?

Should the law come to side with the city of Dallas in its lawsuit to have the Valley View Mall and Event Center demolished, we have already gotten a glimpse of what is to replace it. A piece in Dallas Morning News cites Scott Beck, of renowned development firm Jeff Beck and Sons, on what may come next if the mall is torn down: "1.5 million square feet of retail storefronts, restaurants, residential units, office towers and even a high-rise hotel with condo towers" (Wilonsky, 2018). Capital is moving dynamically within the secondary circuit of urban development - not just flowing into the tertiary. It experiences micro-crises, wherein it over-invests in particular market niches and upon reaching the point of over-accumulation must relocate into yet another within the secondary circuit - urban housing, office buildings, restaurants, and even more retail outlets, this time independent of a spectacular mall's superstructure.

Capital is diversifying its portfolio in the secondary circuit, looking to minimize its risk but maximize its net surplus extraction. In terms of Valley View, Beck wants to create what he calls an "urban village," a more diverse landscape that caters to the uber rich. This is not just an idiosyncrasy of Valley View, either, but rather an unnerving trend. In Plano, Texas, a "one billion dollar plan has finally been approved for Centurion American Development Group to redevelop the [Collin Creek Mall] into a mixed-use project with housing, entertainment and offices" (Ziots, 2019). Quotations of this sort regarding other malls, both dead and dying, are scarily abundant. While America's malls are dying, capital is shifting gears. It is seeking a fresh face, diversifying its urban image, and dynamically pumping investments into variable facets of the urban landscape. Most saliently, this means rampant gentrification related to the inevitable rises in ground rent surrounding the re-developed space. It is easy to envision the consequences of such gentrification on the surrounding poor and working class, who would be forced to leave due to exponentially rising rent. The diversification of capital within the landscape of the secondary circuit has grim implications for already vulnerable urban populations, implications that simply cannot be treated with adequate enough care herein. Understanding what is killing America's malls proves, then, to be a much 
more complex concern than merely positing that online sales, over-malling, or thrift shops are the simple culprits. In truth, the shopping mall is the victim of the very thing that it was erected to generate - capital. Its predatory nature and dynamic movement within the secondary circuit is the killer of the American mall. But you and I aren't off the hook. We are capital's accomplices, and each of us holds a shovel. We are the tightlipped gravediggers burying America's malls, and it is our collective complicity that perpetuates the destructive cycle of capital in our cities. The result: a sea of dead malls litters the landscape, awaiting the bulldozers and wrecking balls that will make way for capital's next ventures atop the ashes.

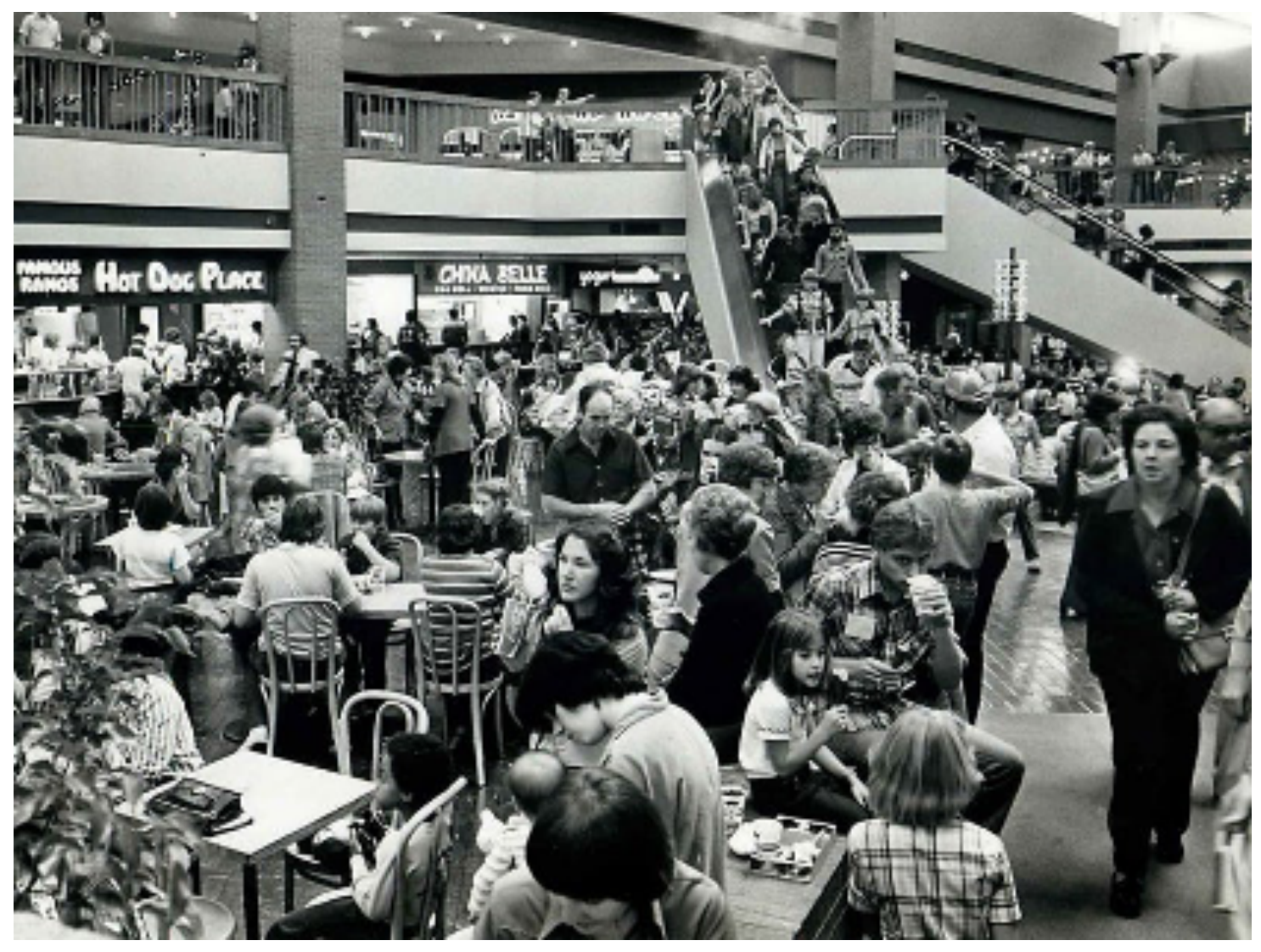

Valley View Mall and Event Center, circa 1978. Source: Grant, 2019

\section{Bibliography}

D’Innocenzio, Anne, et al. "Sears in Denton One of 72 Nationwide to Close as Sales Plunge." Denton Record-Chronicle, 31 May 2018, www.dentonrc.com/business/sears-indenton-one-of-nationwide-to-close-assales/article_bbc5d462-d6d6-5408-93dee8c138421025.html.
Goss, Jon. "The 'Magic of the Mall': An Analysis of Form, Function, and Meaning in a Contemporary Retail Built Environment". 1993, https://www.researchgate.net/publication/24 941.

Grant, Clint. Photograph of Valley View Mall in 1978. "Malls Were Meccas for Black Friday Shoppers Back When Valley View Was New.” Dallas News, Dallas 
News, 23 Nov. 2019, www.dallasnews.com/news/from-thearchives/2019/11/26/malls-were-meccas-forblack-friday-shoppers-back-when-valleyview-was-new/.

Harvey, David. "Flexible

Accumulation through Urbanization

Reflections on 'Post-Modernism' in the American City." 1990. pp. 251272. JSTOR. Web. DOI: www.jstor.org/stable.

Richter, Wolf. "Nothing Can Stop the Shift to Online Shopping." Business Insider. 20 November 2017, https://www.businessinsider.com/nothingcan-stop-the-shift.

Sanburn, Josh. "America's Malls and Department Stores Are Dying Off." Time, Time, 20 July 2017, time.com/4865957/death-and-life-shoppingmall/.

Tretter, Eliot, M., et al. Shadows of a Sunbelt City: The Environment, Racism, and the Knowledge Economy in Austin. University of Georgia Press, 2016, www.jstor.org/stable/j.ctt189tshn.

Wilonsky, Robert. "Dallas Finally Sues Valley View Center's Owners over the Mess It Is.” Dallas News, 13 Sept. 2018, www.dallasnews.com/opinion/commentary/ 2018/09/13/dallas-finally-sues-valley-viewcenter-mess.

Worstall, Tim. "The Shopping Malls Really Are Being Killed By Online Shopping." Forbes, Forbes Magazine, 4 Jan. 2015, www.forbes.com/sites/timworstall/2015/01/ 04/the-shopping-malls-really-are-beingkilled-by-online-shopping/\#58e176056fbb. Ziots, Megan. "One Billion Dollar Plan to Bring an Old Texas Mall Back From the Dead." PaperCity News. 23 April 2019, https://www.papercitymag.com/fashion/plan o-collin-creek-mall/. 